\title{
Ultrastructure of Delicata sinensis KraMmer et Metzeltin and D. williamsii sp. nov. (Bacillariophyta) from China
}

\author{
Bing LIU ${ }^{1 *}$, Saúl BLANCO ${ }^{2} \&$ Qing-yan LAN ${ }^{1}$
}

\author{
${ }^{1}$ Key Laboratory for Ecotourism of Hunan Province and College of Biology and Environmental Science, Jishou \\ University, Jishou 416000, China; *Corresponding author e-mail: jsulb@outlook.com \\ ${ }^{2}$ Department of Biodiversity and Environmental Management, University of León, 24071 León, Spain. Current \\ address: The Institute of the Environment, La Serna, 58, 24007 León, Spain
}

\begin{abstract}
Two sympatric species, Delicata sinensis Krammer et Metzeltin and D. williamsii sp. nov. are studied under light and scanning electron microscopy. Both species possess open valvocopulae, which is reported for the first time within the genus. Delicata sinensis often exhibits a semifascia-like central area but sometimes only a little broadened central area bordered by a few shortened striae in the middle part of the dorsal side. Regarding D. williamsii, a freshwater, epilithic taxon, it exhibits a unique combination of characters: a dorsiventral valve outline, non-produced ends and, remarkably, widely spaced 2-3 very long striae in the middle part of the dorsal side. Its status as a distinct species can be confirmed by the presence of 3-4 stigmata on the central area of the ventral side and the undulated striae, more distinctly near the pole. Delicata williamsii is finally compared morphologically with similar Delicata species.
\end{abstract}

Key words: dorsiventral, new diatom species, open girdle band, stigma, undulated striae, Wuling Mountains

\section{INTRODUCTION}

The diatom genus Delicata was segregated from Cymbella sensu lato by Krammer in 2003. Important diagnostic characters of the genus Delicata include: dorsiventral valves, strongly ventrally curved proximal raphe branches, distal raphe fissures deflected dorsally, foramina with a tendency to form undulated transapical structures, and the absence of apical pore fields. In Krammer (2003) 15 taxa were listed within Delicata. Subsequently, MeTZeLtin \& Lange-Bertalot (2007) described two new Delicata species, and a new addition to the genus was reported by Le CoHU \& AzÉmAR (2011). Up to date, there are 18 species included within Delicata, which are distributed from the tropics to the subarctic zone. These taxa can be divided two groups: one with non-produced or barely produced ends (13 taxa), the other with produced ends (5 taxa) (Table1).

As in many diatom genera, SEM micrographs can be used to make an accurate comparison among different taxa. However, in Krammer (2003) only Delicata delicatula (KüTZING) KRAMmER, D. judaica (LANGEBertalot et Krammer) Krammer et Lange-Bertalot, D. minuta Krammer, and $D$. verena LANGE-BerTaLOT et KRAMMER were illustrated by SEM micrographs. In Metzeltin \& LANGe-Bertalot (2007), D. cubana
Metzeltin et Lange-Bertalot was additionally studied under SEM. Finally, a recent new species of Delicata, D. couseranensis Le CoHu et LANGE-Bertalot has been also investigated with SEM (LE COHU \& AzÉMAR 2011). There is only one member of the genus described from China (the type locality is Sky lake, Tianchi, Uyguren-province, China): Delicata sinensis KRAMMER et Metzeltin, which was also reported in other locality of China (Li et al. 2007). However, to date D. sinensis had never been studied under SEM.

The Wuling Mountains Area (Fig. 1), where the Wuling Mountains stretch across Chongqing, Hunan, Hubei and Guizhou Provinces (China), is one of the ten biodiversity hotspot eco-regions that should become a conservation priority in China (TANG et al. 2006). By the end of 2014, 19 National Nature Reserves have been established in this mountainous region. In or near these reserves there are numerous streams/rivers where the diatom flora is underexplored. The study of the diatoms in this mountainous area began in 2014; and many interesting new species have been found ever since (e.g. Liv et al. 2016). In the present study we investigate two sympatric species, $D$. sinensis and $D$. williamsii sp. nov., under LM and SEM, providing morphological and ultrastructural details aiding identification and discrimination with respect to similar Delicata taxa 


\section{Material AND Methods}

The study site is the course of a river running along Wudaoshui Town close to Badagongshan National Nature Reserve, Hunan Province, China (Fig. 1). Badagongshan National Nature Reserve is one of the 19 reserves established in Wuling Mountains Area, China. Wuling Mountains Area belongs to the mountain climate, which is a transition from sub-tropical to warm temperate climate. The average temperature is $13.5-17.0^{\circ} \mathrm{C}$ and the average precipitation is within the range $1100-1600 \mathrm{~mm}$. In this study, the diatom sample was taken from a sampling point named Jinlong power station (2943'7.1"N, 109 $\left.54^{\prime} 50.9^{\prime \prime} \mathrm{E}\right)$, at Wudaoshui Town.

The sample was collected on $30^{\text {th }}$ September 2015 from stones in a river running along Wudaoshui Town. Diatom specimens were scraped from stones using toothbrushes and then washed into $100 \mathrm{ml}$ sampling bottles and fixed with $70 \%$ ethanol. Together with the sample collection, GPS coordinates and several water characteristics were recorded.

In the laboratory, diatom samples were processed using $10 \% \mathrm{HCl}$ and $30 \% \mathrm{H}_{2} \mathrm{O}_{2}$. Permanent glass slides were prepared using Naphrax ${ }^{\circledR}$ mountant. These slides were examined and imaged using a Leica DM3000 light microscope (LM) and a Leica DFC425C camera. For scanning electron microscopy, several drops of cleaned diatom material were air-dried onto glass coverslips. The selected coverslips were attached to an aluminum stub using double-sided adhesive conductive carbon tape and sputter-coated with platinum. Samples were examined and imaged using a Sigma HD Scanning Electron Microscope at $2-10 \mathrm{kV}$ in Huaihua University, China.

\section{ReSULTS}

Delicata sinensis Krammer et Metzeltin (Figs 2-17) Light microscopy (Figs 2-7): Concerning the measurements, the diagnosis should be amended as below. Length 21-41 $\mu \mathrm{m}$, breadth 5.9-8.0 $\mu \mathrm{m}$, maximum length/breadth ratio 5.4 , and striae $14-16 / 10 \mu \mathrm{m}$ in the middle ventral portion $(\mathrm{n}=31)$ instead of length $21-38 \mu \mathrm{m}$, breadth 6.3-7.4 $\mu \mathrm{m}$, maximum ratio length/breadth ratio 5.1, and striae $14-16 / 10 \mu \mathrm{m}$ in the middle dorsal portion (KRAMmer 2003).

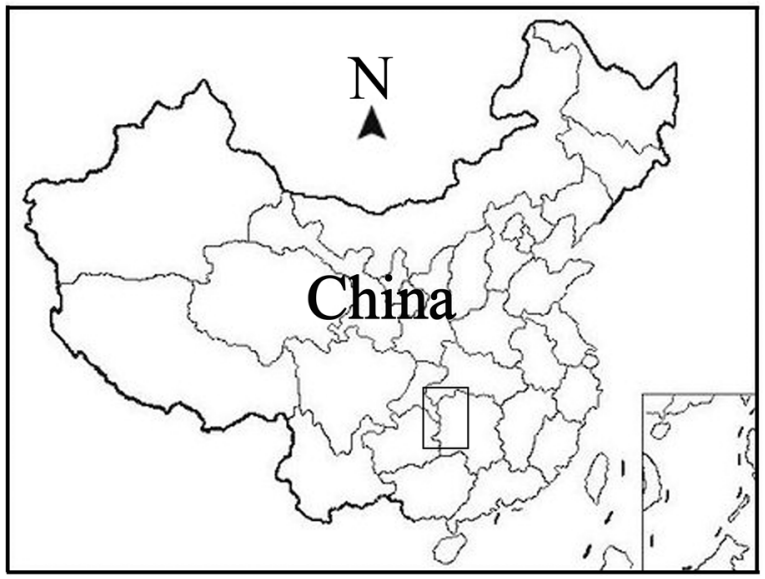

Scanning electron microscopy (Figs 8-17): Valve slightly dorsiventral, lanceolate (Figs 8-10). Axial area curved, ventrally displaced near the central area (Figs 8-9). Central area often forming a semifascia (Figs 8-9, 11). Proximal raphe branches ventrally deflected (Figs 8-9, 11), central pores discernible (Fig. 11), distal raphe fissures strongly curved towards the dorsal side (Figs 8-9, 12). Striae composed of tilde-shaped areolae (Fig. 12, arrowheads) and slightly radiate throughout (Figs 8-9). Striae exhibit distinctly wave-shaped structures and run onto the mantle without interruption (Figs 11-12). Stigmata absent, but one slit-like areola is present on the ventral side near the central nodule (Fig. 11, arrowhead). Apical field pores also absent (Fig. 12). Valvocopula possessing a single row of poroids that separates pars interior and exterior, and its open nature can be confirmed (Fig. 10 , arrow). Internally, a semifascia-like central area is present (Fig. 13, double-head arrow) and sometimes the central area is bordered by a few shortened striae (Fig. 15 double-head arrow). Axial area linear, broadened near the center. Terminal raphe endings running into helictoglossae. A slit-like internal opening is present (Figs 14-15, arrows). Striae are alveolus internally (Figs 13-17), composed of tilde-shaped or round internal openings which are covered by hymens (Fig. 16, arrows).

Delicata williamsii BIng LIU et S. BLAnco sp. nov. (Figs 18-47)

Description

Light microscopy (Figs 18-37): Valves dorsiventral, ends not protracted, acutely rounded. Length 15-29 $\mu \mathrm{m}(22.5 \pm 2.5 \mu \mathrm{m})$, breadth 4.7-6.2 $\mu \mathrm{m}(5.5 \pm 0.4 \mu \mathrm{m})$, maximum length/breadth ratio $5.2(\mathrm{n}=45)$. Axial area

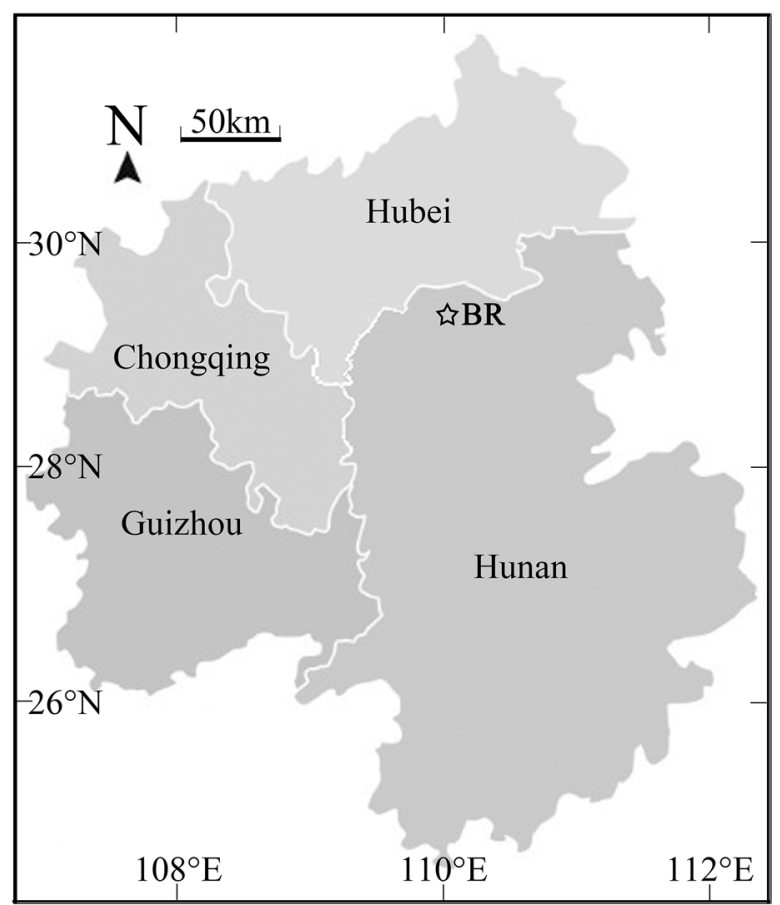

Fig. 1. Map of the study site: (BR) Badagongshan National Nature Reserve. 
narrow, curved, ventrally displaced. In the middle portion of the dorsal side, two or three very long striae have two patterns: one pattern is a stria located exactly on the middle of the dorsal side and two more striae widely evenly standing on each side (Figs 18-27), the other being two very long striae distinctively widely spaced so that the central area is nearly a dorsal semifascia (Figs 28-37). Raphe slightly lateral, narrowing towards the distal ends, becoming reverse-lateral towards the

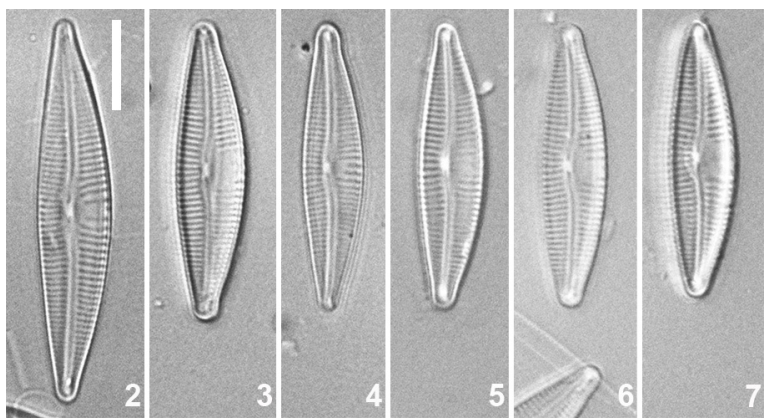

Figs 2-7. Delicata sinensis, LM: $(2,4)$ two valves with central area bordered by a few shortened striae; $(3,5-7)$ A central area with semifascia. Scale bar $10 \mu \mathrm{m}$ (in Fig. 2) for all figures.
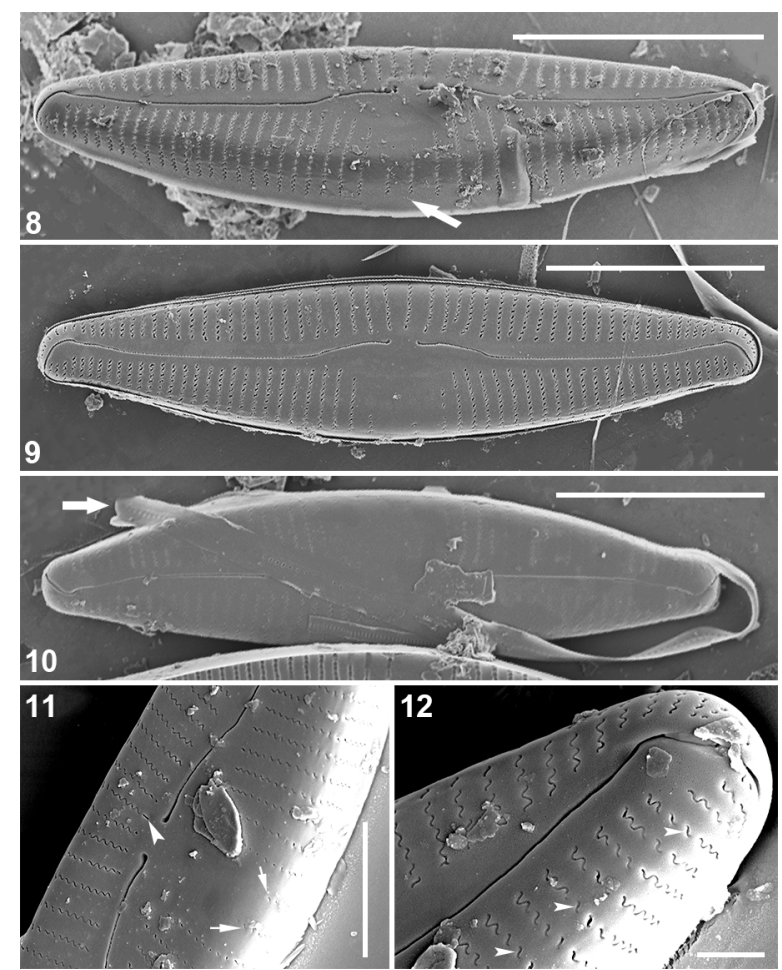

Figs 8-12. Delicata sinensis, SEM, external view: (8) a whole valve, note the undulated striae running onto the mantle, central area bordered by a few shortened striae (arrow); (9) a whole valve, note the tilde-shaped areolae, central area formed by a dorsal semifascia; (10) a valve showing the open valvocopula (arrow); (11) middle part of a valve, showing a slit-like areola (arrowhead), two shortened striae on the middle of the dorsal side; (12) a valve apex, showing the tilde-shaped areolae (arrowheads) aligned in distinctive undulated striae, running onto the mantle. Note the absence of apical pore fields. Scale bars $10 \mu \mathrm{m}$ (8-10), $5 \mu \mathrm{m}$ (11), $2 \mu \mathrm{m}$ (12). proximal ends. Striae slightly radiate throughout. Striae in the middle portion (dorsal) $12-16 / 10 \mu \mathrm{m}(13.9 \pm 1.0$ in $10 \mu \mathrm{m}, \mathrm{n}=45)$, becoming denser towards the ends.

Scanning electron microscopy (Figs 38-47): valve dorsiventral with nonproduced ends (Figs 38-40). Axial area narrow, curved, ventrally displaced near the central area (Figs 38-40). In the middle portion of the dorsal side, two or three very long striae have two patterns: one pattern is a stria located exactly on the middle of the dorsal side and two more striae widely evenly standing on each side (Figs 38-39, 42), the other being two very long striae distinctively widely spaced so that the central area is nearly a dorsal semifascia (Fig. 40). Proximal raphe branches ventrally deflected, central pores present (Figs 38-40, 42), distal raphe fissures strongly curved towards the dorsal side (Figs 38-41). Striae composed of tilde-shaped areolae only near the apex (Fig. 41, arrow) and slightly radiate throughout (Figs 38-40). Striae wave-shaped only near the apex (Fig. 41) and running onto the mantle without interruption (Figs 39-40). Valve face puncta $45-50 / 10 \mu \mathrm{m}(\mathrm{n}=4) .3-4$ stigmata present on the ventral side near the central nodule (Figs 38-40, arrowheads). Apical pore fields absent (Figs 40-41). Valvocopula possessing a single row of poroids that bisects pars interior and exterior, and its open nature can be confirmed (Fig. 39, arrow).

Internally, in the middle portion of the dorsal side, two or three very long striae have two patterns:

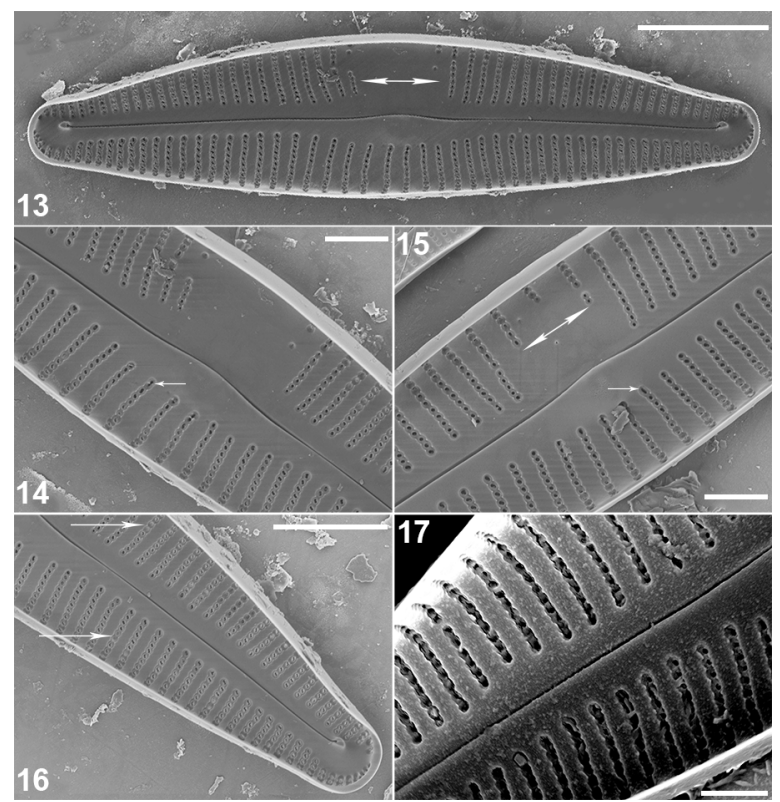

Figs 13-17. Delicata sinensis, SEM, internal view: (13) one whole valve, note the central area forming a dorsal semifascia (doublehead arrow); (14-15) two middle parts of the valve, note the central area bordered by a few shortened striae (double-head arrow), and a slit-like areola present on the ventral side (arrows); (16) a valve apex, showing that the alveolus striae and the round or tilde-shaped internal openings of the areolae covered by hymens (arrows); (17) one eroded part of the valve, note the thin silica layer connecting the areolae. Scale bars $5 \mu \mathrm{m}(13,16), 2 \mu \mathrm{m}(14-15,17)$. 
one pattern is a stria located exactly on the middle of the dorsal side and two more striae widely evenly standing on each side (Figs 43, 45), the other being two very long striae distinctively widely spaced so that the central area is nearly a dorsal semifascia (Fig. 44). Axial area linear, broadened near the center. Terminal raphe endings running into helictoglossae. 3-4 stigmata present on the ventral side near the central nodule (Figs 43-45, arrowheads). Each stigma surrounded by siliceous protuberances (Fig. 46, arrow). Striae are alveolus internally (Figs 43-47), composed of tilde-shaped or round internal openings which are covered by hymens (Fig. 47, arrows).

Holotype (designated here): slide G201608, the Herbarium of Jishou University, Hunan, People's Republic of China. Isotype (designated here): slide BM 101859, The British Museum of Natural History, London.

Iconotype: Fig. 18.

Type locality: The river course near Jinlong power station (29॰43'7.1"N, 10954'50.9"E), Wudaoshui Town close to Badagongshan National Nature Reserve, Hunan Province, China (Coll. BING LIU, 09/30/2015).

Habitat: freshwater, benthic.

Etymology: This taxon is dedicated to our admired diatomist Dr. David M. WiLliams (The Natural History Museum, London, United Kingdom).

Ecology and Distribution: The following environmental parameters were measured in the field. Electric conductivity was $219.3 \pm 1.2 \mu S . \mathrm{cm}^{-1}, \mathrm{pH}$ was $8.8 \pm 0.2$, and water temperature was $17.9 \pm 0.3^{\circ} \mathrm{C}$. Since the diatom sample was scraped off the surface of stones and the water electric conductivity is above $200 \mu \mathrm{S} . \mathrm{cm}^{-1}$, Delicata williamsii can be considered an epilithic diatom characteristic of moderate electrolyte content freshwaters. So far, D. williamsii is only known from the type locality.

\section{Discussion}

Delicata sinensis is distinguished from other Delicata taxa by the dorsal semifascia and the slightly dorsal bent valve ends characteristic of larger specimens. Our LM observations fit well with the original description of $D$. sinensis. Our SEM observations, the first reported in the literature, show its undulated striae throughout the valve, which are very similar to those of the type species $D$. delicatula. No stigma is found in D. sinensis; however, one slit-like areola is present on the ventral side near the central nodule (Fig. 11, arrowhead). Internally, the opening of this slit-like areola is simple, therefore it is not a true stigma as present in many taxa of the genus Cymbella (see below).

Table 1 shows a comparison between Delicata williamsii and other 18 taxa within Delicata. Delicata williamsii has not produced ends, so that it can be easily separated from $D$. apiculata KRAMMER, D. capitata Krammer, D. delicatula, D. gerloffii (VAN LANDINGHAM) KRAMMER, and $D$. sinensis, all of which possess distinctive protracted ends. Delicata williamsii has a stria density of 12-16 in $10 \mu \mathrm{m}$, while D. aequistriata KrAMMER et Lange-Bertalot, D. costei (Maillard) Krammer et Lange-Bertalot, D. gadjiana (Maillard) Krammer,
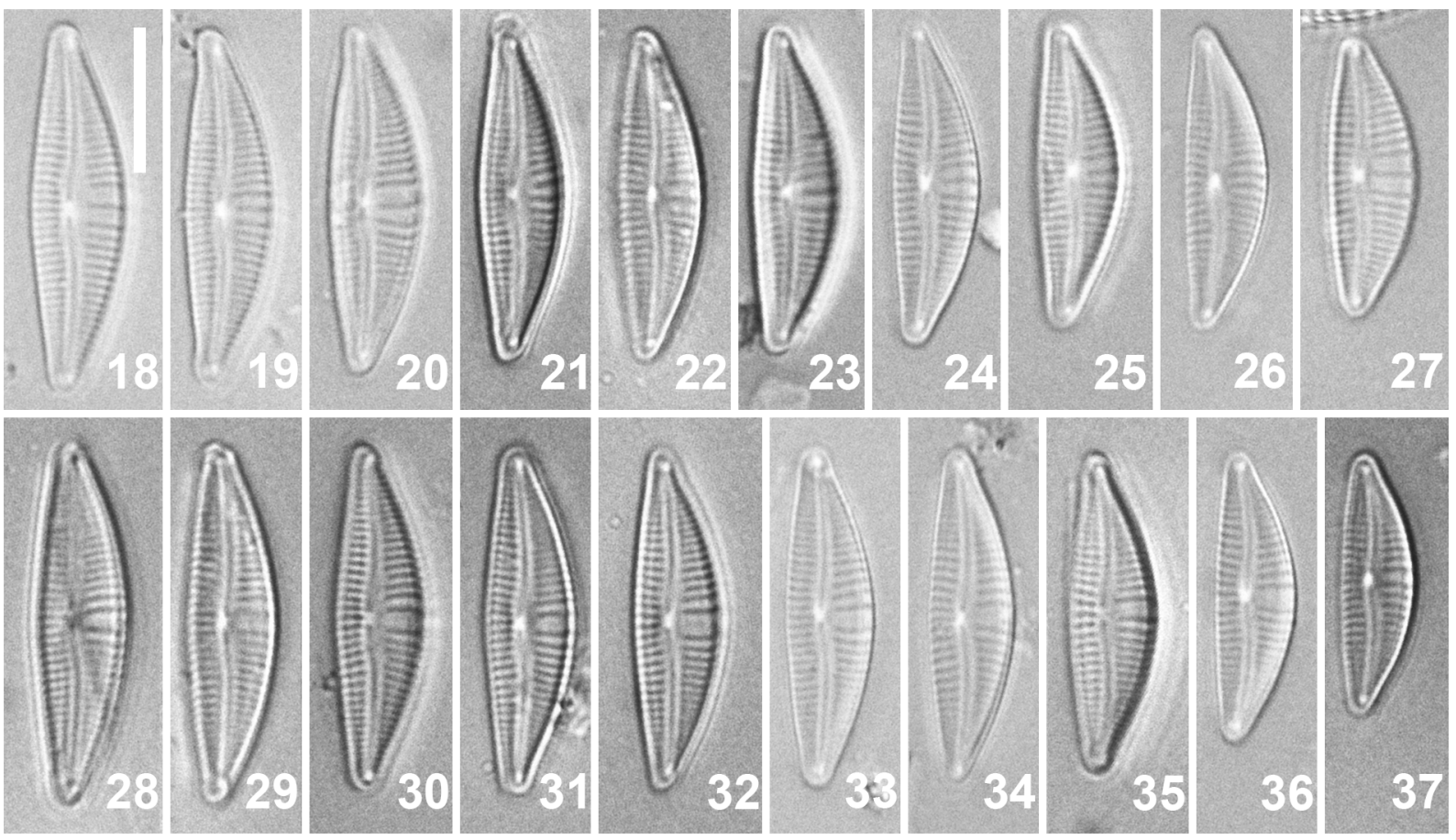

Figs 18-37. Delicata williamsii sp. nov., LM: (18) iconotype; (18-27) ten valves forming a diminution series, note a long stria located exactly on the middle of the dorsal side; (28-37) ten valves forming a diminution series, note the two striae distinctively widely spaced so that the central area is nearly a dorsal semifascia. Scale bar $10 \mu \mathrm{m}$ (in Fig. 18) for all figures. 
D. judaica, D. minuta, D. neocaledonica Krammer, D. nepouiana KRAMMER, and D. spitsberensis KRAMMER all have at least 16 or more striae in $10 \mu \mathrm{m}$. Delicata cubana has longer valves and lower puncta density. Delicata. krammeri Metzeltin, LANGE-Bertalot et GARCÍA-RodríGUEZ has larger valve dimensions. Delicata sparsistriata KRAMMER has somewhat larger valves and a lower puncta density. Delicata verena has larger valve dimensions and coarser puncta. The most similar species to $D$. williamsii is $D$. sparsistriata. In the original description of $D$. sparsistriata it is characterized by having "central few striae on the dorsal side sometimes slightly farther apart than those above and below". Contrastingly, $D$. williamsii has two or three very long striae, often remarkably widely spaced.

In our ultrastructural study of $D$. williamsii, stigmata are first reported for the genus Delicata. Another novel contribution to the genus Delicata is that both $D$.
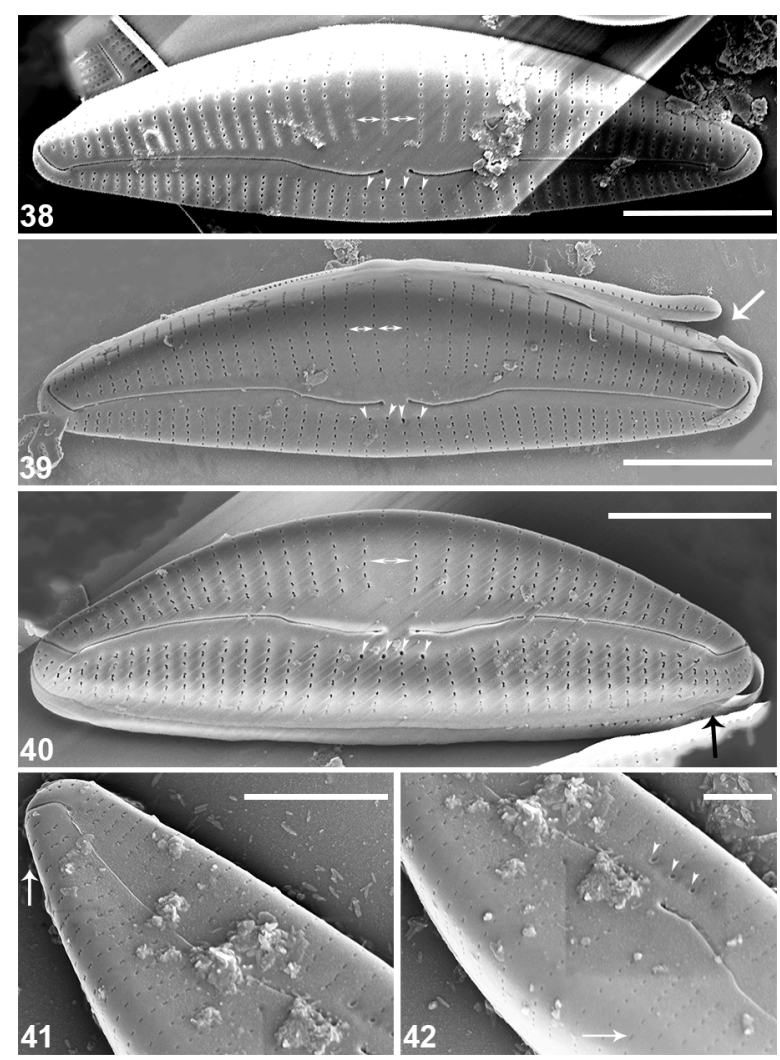

Figs 38-42. Delicata williamsii sp. nov., SEM, external view: (38) a whole valve, note the three striae widely spaced in the middle of the dorsal side (two double-head arrows), and four stigmata on the ventral side (four arrowheads); (39) a whole valve, note the three striae widely spaced in the middle of the dorsal side (two double-head arrows), the four stigmata on the ventral side (four arrowheads), and the open valvocopula (arrow); (40) a whole valve, note that two striae distinctively widely spaced form the central area, which is nearly a semifascia on the dorsal side (double-head arrow), four stigmata occur on the ventral side (four arrowheads), and the valvocopula is open (arrow); (41) an apex, note the tilde-shaped areolae forming undulated striae near the pole; (42) a middle part of the valve, note the round or slightly transapically elongated areolae (arrow) and the four stigmata (three arrowheads). Scale bars $5 \mu \mathrm{m}(38-41), 2 \mu \mathrm{m}$ (42). sinensis and $D$. williamsii possess open valvocopulae (Figs 10, 39). According to Krammer (2003) "stigmata are not characterized by round pores near the central area but by a few unequivocal construction of the stigma alveolus in the valve interior (e.g. present in many taxa of the genus Cymbella)". Following the criteria proposed by REICHARDT (2009) to distinguish stigmata from similar structures, it is evident that $D$. williamsii has 3-4 stigmata present on the ventral side near the central nodule, which can be observed from the internal view of the valves, i.e. internally the ventral stigma openings occur with teeth-like ingrowths and directly adjacent to the striae (Figs 43-46). The internal openings of these stigmata are very similar to those of Cymbella cosleyi Bahls (BAHLS 2013, p. 11, Fig. 20). Although the absence of stigmata is a definitely characteristic of the genus (KRAMMER, 2003) in comparison to other similar cymbelloid taxa, we agree with other authors (see KociOLEK \& WiLliams 2015 for a review) suggesting that not every taxon in a certain genus have to possess all the features used to diagnose that genus. Moreover, as mentioned above, there
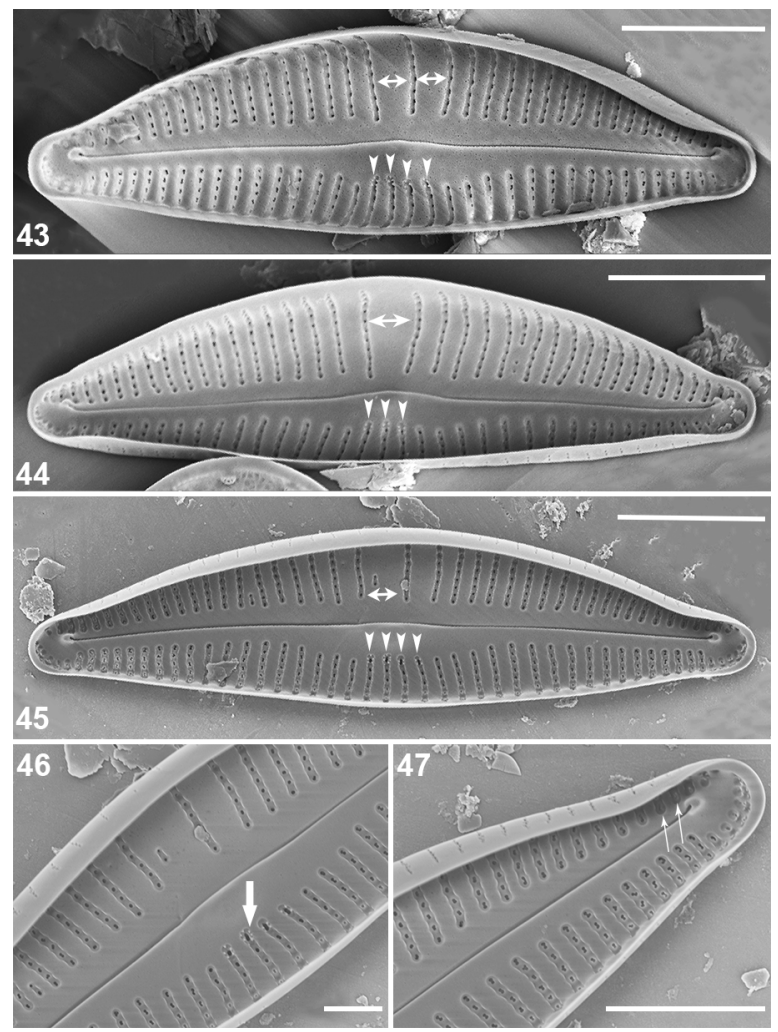

Figs 43-47. Delicata williamsii sp. nov., SEM, internal view: (43) a whole valve, note the three striae widely spaced in the middle of the dorsal side (two double-head arrows), and the four stigmata on the ventral side (four arrowheads); (44-45) two valves, note that two striae distinctively widely spaced form the central area, which is nearly a semifascia on the dorsal side (double-head arrow), three or four stigmata occur on the ventral side (arrowheads); (46) a middle part of the valve, note four stigmata surrounded by siliceous protuberances on the ventral side (arrow), alveolus striae, and round, slightly elongated or tilde-like internal opens; (47) an apex, note the internal opens covered by hymens (arrows). Scale bars $5 \mu \mathrm{m}$ (43-45, 47), $2 \mu \mathrm{m}(46)$ 


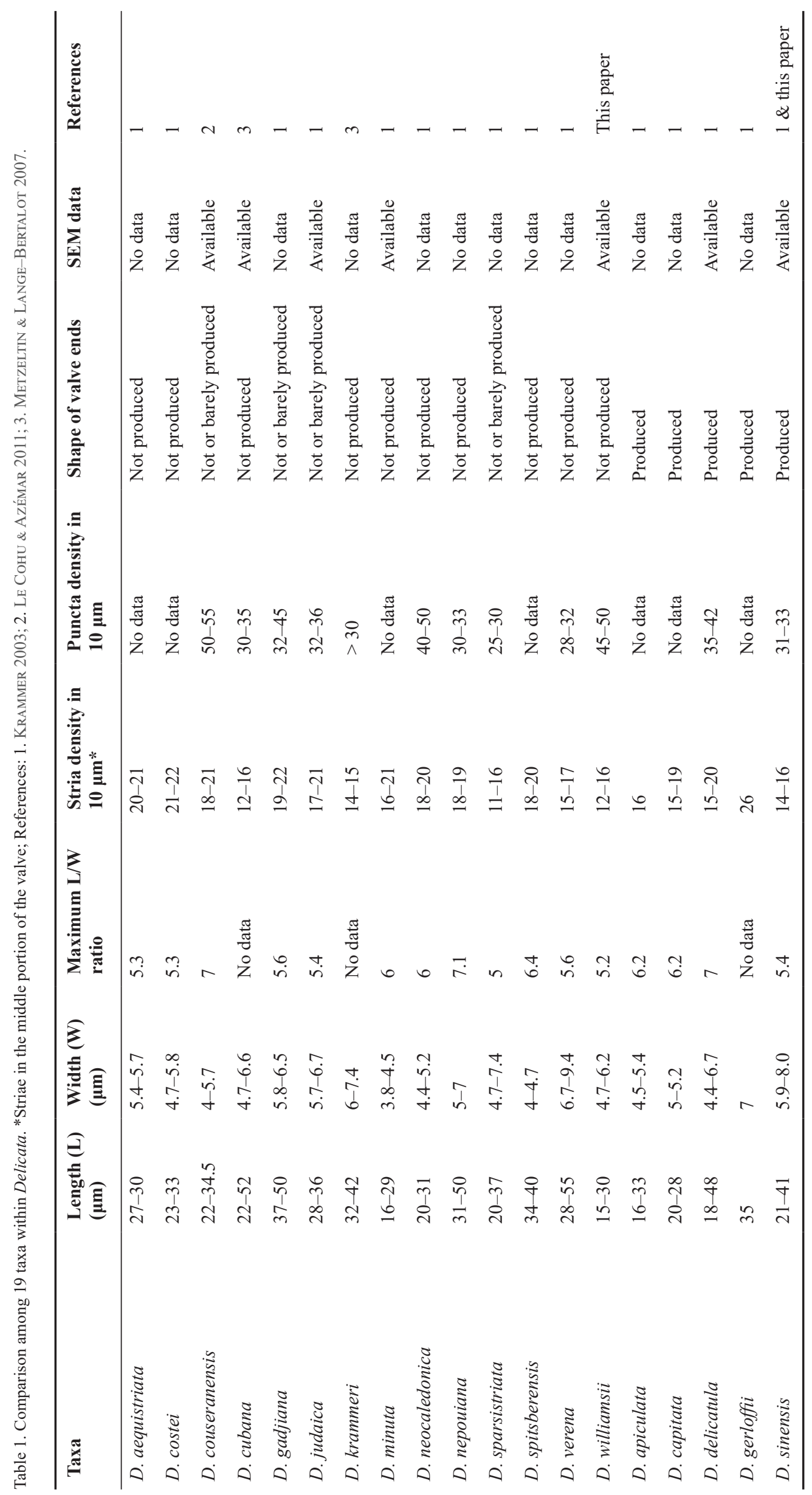


are only six taxa previously investigated with SEM (see Table 1.) and presumably other Delicata taxa actually share this feature. If the stigma is not distinct from the LM images, it is impossible to confirm without checking the interior of the valve under SEM.

In summary, our study reports unobserved features for this relatively poorly known diatom genus, which suggest that its actual diversity may be underestimated. We provide additionally a taxonomic contribution to the algal flora of China and to the biogeographical range of the genus Delicata.

\section{ACKNOWLEDGEMENTS}

We are grateful to Mr. Xin YANG \& Huanfan ZHANG of Huaihua University for help with SEM operation and photography, to Xiaoyan JIANG, Jingjing XU, Yongda OU \& Su Li for assistance in the field, and to the anonymous referee for his/her useful comments. This work was supported by the National Natural Science Foundation of China (No. 31760051) and the key course of Hunan Province (Ecology)/ Jishou University.

\section{REFERENCES}

BAHLS, L. (2013): New diatoms (Bacillariophyta) from western North America. - Phytotaxa 82: 7-28.

Kociolek, J.P. \& Williams, D.M. (2015): How to define a diatom genus? Notes on the creation and recognition of taxa, and a call for revisionary studies of diatoms. Acta Botanica Croatica 74: 195-210.

Krammer, K. (2003): Cymbopleura, Delicata, Navicymbula, Gomphocymbellopsis, Afrocymbella. - In: LANGEBERTALOT, H. (ed.): Diatoms of Europe, Diatoms of the European Inland waters and comparable habitats, Vol. 4. - 529 pp., A.R.G. Gantner Verlag K.G. - Rugell.

Le Cohu, R. \& AzÉmar, F. (2011): Étude morphologique de quelques Cymbellaceae des Pyrénées francaise incluant la description d〉une espèce nouvelle: Delicata couseranensis sp. nov.. - Cryptogamie Algologie 32: 131-155.

Li, Y.L.; Gong, Z.J.; Xie, P. \& Shen, J. (2007): New species and new records of fossil diatoms from China. - Acta Hydrobiologica Sinica 31: 319-324.

LiU, B.; Blanco, S.; Long, H.; XU, J. \& JiANG, X. (2016): Achnanthidium sinense sp. nov. (Bacillariophyta) from the Wuling Mountains Area, China. - Phytotaxa 284: 194-202.

Metzeltin, D. \& Lange-Bertalot, H. (2007): Tropical Diatoms of South America II. Special remarks on biogeography disjunction. - Iconographia Diatomologica 18: 1-877.

REICHARDT, E. (2009): Silikatauswüchse an den inneren Stigmenöffnungen bei Gomphonema-Arten. - Diatom Research 24: 159-173.

TANG, Z.Y.; WANG, Z.H.; Zheng, C.Y. \& FAnG, J.Y. (2006): Biodiversity in China's mountains. - Frontiers in Ecology and the Environment 4: 347-35.

(C) Czech Phycological Society (2018)

Received December 23, 2016

Accepted March 8, 2017 